\title{
Management of Zakat at BAZNAS Regency Sidrap During COVID-19's Pandemic
}

\author{
A. Rio Makkulau Wahyu', Wirani Aisiyah Anwar² \\ STAI DDI Sidrap ${ }^{1}$, STAI DDI Sidrap ${ }^{2}$ \\ Parepare City South Sulawesi Province ${ }^{1}$, Parepare City South Sulawesi Province ${ }^{2}$ \\ E-mail: andiriom@gmail.com
}

\begin{abstract}
,
Zakat is an obligation for every Muslim who can purify his soul to zakat Fitrah and purify his property for Zakat Maal. Zakat must be managed properly so that the distribution of the property can run effectively and targeted to the Mustahik in the moment of the current Covid19 pandemic. Baznas has made renewal in zakat management both in terms of collecting, distributing, and utilization of zakat funds. For example, in the case of fundraising Zakat is done by a digital system. The purpose of this research is to explain the management of Zakat done by the Baznas Sidrap Regency in maximizing the distribution of the accumulated zakat funds. The study was conducted using a combination of library and field research using a qualitative method with descriptive analysis. The research location was at Sidrap District. The results showed that zakat funds can be utilized to the fullest extent possible for the welfare of the Mustahik both consumptive and productive. In distributing the fund zakat Baznas Sidrap Regency has channeled the funds amounting to Rp.1,2 billion since the period of Covid-19 pandemic with the main channeling of zakat funds in remote areas that have been affected by Covid-19 pandemic, in the form of food aid for the consumptive.
\end{abstract}

Keywords: Covid-19 Pandemic, Zakat, Baznas Sidrap

\section{INTRODUCTION}

On March 11, 2020, the World Health Organization (WHO) declared an outbreak of the disease caused by the coronavirus COVID-19 as a global pandemic. The declaration of this status was due to positive cases outside China which had increased thirteen times in 114 countries with total deaths at that time reaching 4,291 people. WHO states that so far there has never been a pandemic triggered by a coronavirus and at the same time, there has never been a pandemic that can be controlled. On that basis, the WHO asks countries to take urgent and aggressive action to prevent and overcome the spread of the COVID-19 virus. (Valerisha \& Putra, 2020)

The spread and prevalence of positive cases of COVID-19 has continued to move rapidly and has increased since the first cases were announced on March 2, 2020. Until now, as of July 23, 2020, there were 1,906 confirmed positive cases of COVID-19, bringing the total to 93,656 people. While 36,917 people were still in treatment or $39.4 \%$ of the total confirmed and cases recovered had an increase of 1,909 so that the total recovery was 52,164 people or $55.7 \%$ of the total confirmed. Meanwhile, there were 117 additional cases of death on 23 July 2020 with a total of 4,567 people or as much as $4.9 \%$ of the total confirmed. (WHO, 2020)

The COVID-19 pandemic (Coronavirus Disease 2019) has shaken the world. Various countries are currently focusing not only on the health problems of their citizens but also on the socio-economic impact of this pandemic. Until April 16, 2020, a total of 2,088,861 people contracted the coronavirus and 134,755 of them died. The Indonesian government has done the same by responding quickly, issuing various preventive measures such as an appeal for physical and social distancing, until the 
most recent is Large-Scale Social Restrictions (PSBB) to prevent more widespread spread. Socio-economically, the global impact of this pandemic will result in the layoff of 25 million workers (Termination of Employment) or their wages cut. The Organization for Economic Cooperation and Development (OECD) report at the end of March 2020 projects that global GDP will only grow by $2.4 \%$. while the G-20 countries only grew by $2.5 \%$. This decline in GDP, if only in the range of $2 \%$, according to the ILO (International Labor Organization) will cause an increase in the unemployment rate of 5.3 million people, and create job uncertainty for 3.5 million to 7 million people and this has an impact on increasing poverty. ( $\mathrm{P}$ et al., 2020)

The impact of this COVID-19 prevention policy will be felt by those who fall into vulnerable groups of people. Several options can be made in dealing with this problem, in the concept of Islamic economics, it is known as zakat, infaq, alms, and waqf. This is an instrument of wealth distribution in the Islamic economic system.

The first option: Distribution of direct cash assistance originating from zakat, donations, and alms, both from zakat collection units and from the community. Especially for zakat that is paid, the distribution can be focused on the poor who are directly affected by COVID-19, as one who is entitled to receive it (mustahik). This point is an Islamic Economic filantropi scheme that has great potential for the economy of the community. This fund can also be provided for capital assistance for superior businesses during a crisis. Amid a crisis, not a few business sectors or Micro, Small and Medium Enterprises (MSMEs) are struggling to survive. This business is often difficult to survive because of limited capital.

Second option: Strengthening cash waqf with cash waqf schemes, productive waqf, and waqf linked sukuk needs to be improved. The Indonesian Waqf Board (BWI) needs to work with sharia financial institutions to promote this waqf scheme so that it can be partially used for the development of various waqf-based infrastructure such as the Waqf Hospital (RSW) specifically for COVID-19 victims, waqf Personal Protective Equipment (PPE), masks waqf, waqf polyclinic, Waqf Isolation House (RIW), procurement of waqf ventilators, waqf universities and others. Waqf management must be done professionally, so that waqf can be used in a sustainable manner.

However, this time we will discuss the role of zakat as an instrument to help those affected by the COVID-19 pandemic. The government certainly understands the obstacles faced by most Indonesians. Therefore, to anticipate this policy, the government also implements policies on the economic side, such as providing credit relaxation, pre-employment cards, social assistance, exemption from electricity rates, and so on. The work of the government for the welfare of its people must be appreciated. However, it must also be acknowledged that the role of other institutions is still needed to reduce the impact of COVID-19 on the Indonesian people. One of the institutions that can help the work of the government is the Zakat Management Organization (OPZ). This is because the human resources and funds owned by the OPZ can be managed in such a way as to help people affected by COVID-19. This is where the role of zakat institutions, in this case, Baznas Sidrap district, is the state zakat institution in helping people during a pandemic. Based on this problem the role of 
zakat will be explained as a function and role of religious institutions to realize community welfare and social justice for mustahik zakat.

\section{LITERATURE REVIEW \\ Impact of COVID-19 on the Economy}

In December 2019, cases of mysterious pneumonia were first reported in Wuhan, Hubei Province. The source of the transmission of this case is still uncertain, but the first case was linked to a fish market in Wuhan. From December 18 to December 29, 2019, there were five patients treated with Acute Respiratory Distress Syndrome (ARDS). From December 31, 2019, to January 3, 2020, these cases increased rapidly, marked by 44 reported cases. In less than a month, the disease has spread to various other provinces in China, Thailand, Japan, and South Korea. The sample studied shows the etiology of a new coronavirus. Initially, the disease was temporarily named as 2019 novel coronavirus (2019-nCoV), then WHO announced a new name on February 11, 2020, namely Coronavirus Disease (COVID-19) caused by the Severe Acute Respiratory Syndrome Coronavirus-2 (SARS-CoV-2) virus. This virus can be transmitted from human to human and has spread widely in China and more than 190 countries and other territories. On March 12, 2020, WHO announced COVID-19 as a pandemic. COVID-19 is a new disease that has become a pandemic. This disease should be watched out for because transmission is relatively fast, has a mortality rate that cannot be ignored, and there is no definitive therapy. There are still many knowledge gaps in this field so further studies are needed. (Susilo et al., 2020)

The World Health Organization (WHO) explains that Coronaviruses (Cov) is a virus that infects the respiratory system. This viral infection is called COVID19. The Coronavirus causes common cold to more severe illnesses such as the Middle East Respiratory Syndrome (MERS-CoV) and Severe Acute Respiratory Syndrome (SARS$\mathrm{CoV})$. Coronavirus is zoonotic which means it is transmitted between animals and humans. According to the Indonesian Ministry of Health, the development of the COVID-19 case in Wuhan began on December 30, 2019, when the Wuhan Municipal Health Committee issued a statement "urgent notice on the treatment of pneumonia of the unknown cause". The spread of the Coronavirus is very fast even across countries. To date, 188 countries have confirmed being affected by the Coronavirus. The spread of the Coronavirus that has spread to various parts of the world has an impact on the Indonesian economy, both in terms of trade, investment, and tourism. (Putra \& Dana, 2016)

The economy is one of the important factors in human life. It can be ascertained that in everyday human life it always intersects with economic needs. Economic existence can provide opportunities for humans to meet their daily needs such as food, drinks, clothing, shelter, and so forth. The importance of the economy in human life requires the state to regulate policies on the economy and guarantee the economy of citizens, especially in Indonesia, which proclaims itself as a welfare state. After the COVID-19 problem caused the economy to decline by $5 \%$.

Finance Minister Sri Mulyani stated that in this very tough situation, there would be an increase in the number of poverty figures to 3.78 million people. If there is a 
planned recovery, we hope that the poverty estimate is not as bad as predicted. (Nurhayati \& Halal, R, 2020) The impact of COVID-19 pandemic is affecting the Indonesian economy. The sectors affected during the COVID-19 pandemic are transportation, tourism, trade, health, and other sectors, but the economic sector most affected by COVID-19 is the household sector. (Susilawati et al., 2020) This is what will later lead to increased poverty in Indonesia and cause zakat mustahik will increase, because of that a solution is made in strengthening the management of zakat funds to prosper the mustahik and reduce the high poverty rate in Indonesia.

\section{Zakat Management Theory}

Management is a process or a systematic way to do a job or activity, namely: planning, organizing, direction, and supervision. (Muin, 2011) The manifestation of the birth of the Zakat Law has made the amil zakat body increasingly clean up and show its identity as a professional zakat management institution and able to become a zakat management institution that is trusted by the community. Professionally managed zakat.

Professional management of zakat requires skilled personnel, mastering issues related to zakat, such as muzakki, nisab, haul and mustahik zakat, managers must be dedicated to working lillahi ta'ala, besides being honest and trustworthy. (Sahal Mahfudh, 2007)

The management of zakat will be more empowered by means that the funds collected can be allocated as business capital so that in the next few years mustahik can become muzakki. With good management of zakat is a potential fund that is used to advance the general welfare of all communities, especially the people of Sidrap district, of course with good cooperation between the community and the government.

So it is hoped that the existence of the amil zakat agency in Sidrap district can become an institution that makes people less well off, both in terms of utilization and distribution which is carried out consumptively and productively. Moreover, the state system is decentralized and there is encouragement so that each region can handle its own regional household affairs autonomously with the existence of a legal umbrella regarding zakat in the form of regional regulations on zakat. Law Number 23 of 2011 concerning Zakat Management, which explains that zakat management is an activity of planning, implementing, and coordinating the collection, distribution, and utilization of zakat.

The collection of zakat is carried out by amil zakat by receiving or taking from muzakki on the basis of muzakki notification. Amil can work with banks in collecting zakat muzakki. (Fakhruddin, 2008) Collectors of zakat are in charge of recording and determining muzakki. In this case, the collectors determine the types of assets that are obliged to be subject to zakat and the amount they must pay. Then take and manage it and then handed over to the officers who distribute. Collectors must also understand the law of zakat, for example, matters relating to the type of property, level of nishab, haul, and so on. (M. Quraish Shihab, 1999) 
After Baznas collects zakat, the zakat funds that have been collected are obliged to be distributed to those entitled to receive it according to the provisions of Islamic law. In distributing zakat funds to mustahik, there are three characteristics, namely:

1. It is a grant (giving) and takes into account the priority scale of mustahik needs in each region.

2. Helpful, namely helping mustahik in solving or reducing very urgent/emergency problems.

3. Empowerment, namely helping mustahik to improve their welfare, both individually and in groups through sustainable programs or activities, with revolving funds, to provide opportunities for more recipients.

Meanwhile, in the utilization of zakat, three principles need to be considered, namely:

1. Given to eight asnaf.

2. The benefits of zakat can be received and the benefits are felt.

3. By the needs of mustahik (consumptive and productive).

\section{METHODS}

This study was conducted using a combination method of library research and field research with qualitative methods carried out with descriptive analysis.

\section{DISCUSSION}

Zakat for Muslims is an obligation that has a very fundamental meaning. Apart from being closely related to divine, economic, and social aspects. Among the divine aspects are the many verses of the Alquran mentioning the issue of zakat, including 27 verses that juxtapose the obligation of zakat with the obligation to prayer together. Among them in the Alquran, surah al-Baqarah/2 verse 43 which means: And establish prayers, pay zakat and reconcile with those who bow.

In describing the urgency (position) of zakat, the Alqur'an mentions 72 times (zakat as a form of ma'rifah is mentioned 30 times in the Qur'an, 27 of which are mentioned sequentially in one verse along with the obligation to pray. See, for example QS Al-Baqarah (2): 43, 83, 110; QS al-Nisaa '(4): 77; QS Al-Taubah (9): 5, 11, 18, 71; QS Maryam (19): 31, 55 ; QS Al-Anbiyaa '(21): 73; QS Al-Hajj (22): 41; QS Al-Nuur (24): 55-56; QS Al-Naml (27): 3; and QS Luqman (31) : 4) with various kinds of derivatives. (Zainuddin, 2013) Even the Prophet also placed zakat as one of the main pillars in upholding Islam. (Nuruddin, 2006)

Zakat is seen as one of the five pillars of Islam, namely: shahada, prayer, zakat, fasting, and Hajj. It is very clear in the Quran and hadith regarding the obligation of zakat. Zakat should be carried out for those who have met the requirements, namely the haul and nisab specified, for example, 2.5\% of gold, silver and trade, $5 \%-10 \%$ of agricultural and plantation products, while the form of livestock and the amount of zakat varies depending on on the types of livestock being kept. The payment of zakat is also believed to be part of an effort to clear property from the rights of the poor so that zakat has become part of Islamic teachings that must be fulfilled properly, (Didin Hafidhuddin, 2008) as in the Alquran, surah at-Taubah / 9 verse 103 which translates: 
"Take zakat from part of their property, with that zakat you clean and purify them and pray for them. Surely your prayer (is) peace of mind for them. and Allah is All-hearing, All-knowing. " From this verse, it is illustrated that the zakat issued by muzakki can cleanse and purify their hearts, no longer have a torn nature towards the property, such as greed and stingy. (Zainuddin, 2013)

Zakat is expected to bring fertility rewards and purify the soul from misery and sins. Zakat is a religious institution that functions to realize social justice for all mankind by paying attention to an increasing concern for the less fortunate. Zakat as an economic instrument that is intended to reduce economic disparities that occur, especially in Indonesian society today to face the COVID-19 pandemic.

According to Didin Hafidhuddin, there are at least 3 things related to the COVID19 pandemic, namely:

1. COVID-19 is one of the verses or signs of the signs of Allah SWT's power

2. COVID-19 will give birth to an economic crisis that will take a long time to recover, in the form of an increase in poverty and unemployment that will continue to haunt our country. Casual daily laborers, workers in the informal sector, small traders, mobile traders, as well as the lower classes of society feel the heavy impact.

3. There will be The New Normal or new normality in various areas of life which is now being prepared and introduced to the community. (Didin Hafidhuddin, 2020)

It is a major role for the Indonesian government at this time in undergoing the COVID-19 pandemic by maintaining the safety and health of the Indonesian people as the main focus, then maintaining the rate of economic growth. This is where the role of zakat management organizations is BAZ (Amil Zakat Agency) and Amil Zakat Institution (LAZ). The National Amil Zakat Agency (Baznas) is an official and the only body formed by the government which has the task and function of collecting and distributing zakat, infaq, and alms (ZIS) at the national level.

\section{7akat Institutional Structure}

\section{President}

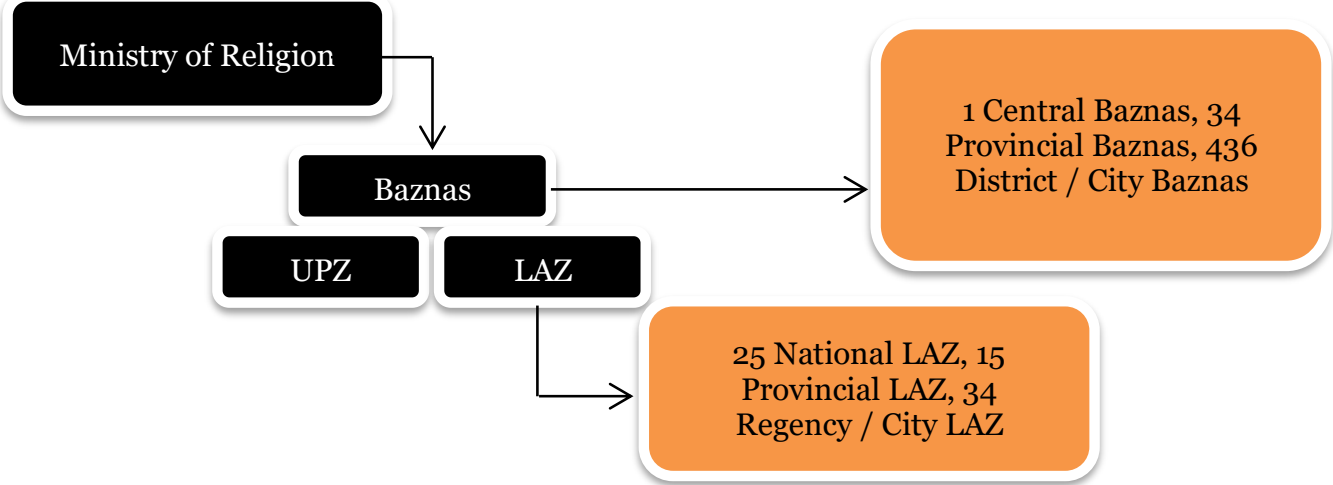

Seeing the potential for zakat in Indonesia, with 544 Zakat Management Organizations (OPZs), Indonesia is the largest amil zakat institution in the world, with 
a national zakat potential of IDR 233 trillion. This makes Indonesia the number 1 most generous Muslim country from the World Giving Index. (Kamaruddin \& Amil, n.d.)

The role of Baznas and Laz is helping the country fight for the welfare of the people during the COVID-19 pandemic. Meeting basic needs must be a priority in the recession phase due to this pandemic to prevent hunger, crime, and anarchy.

Baznas has made renewals in the management of zakat both in terms of collection, distribution, and utilization of zakat funds that will be given to mustahik. Baznas has made various innovations in collecting zakat during the COVID-19 pandemic. This innovation is realized with various strategic steps as a form of adaptation to accommodate the needs of the community in distributing zakat during the pandemic. Baznas innovation focuses on three things, namely: Campaigns or invitations for zakat, payment services, and opening donation channels.

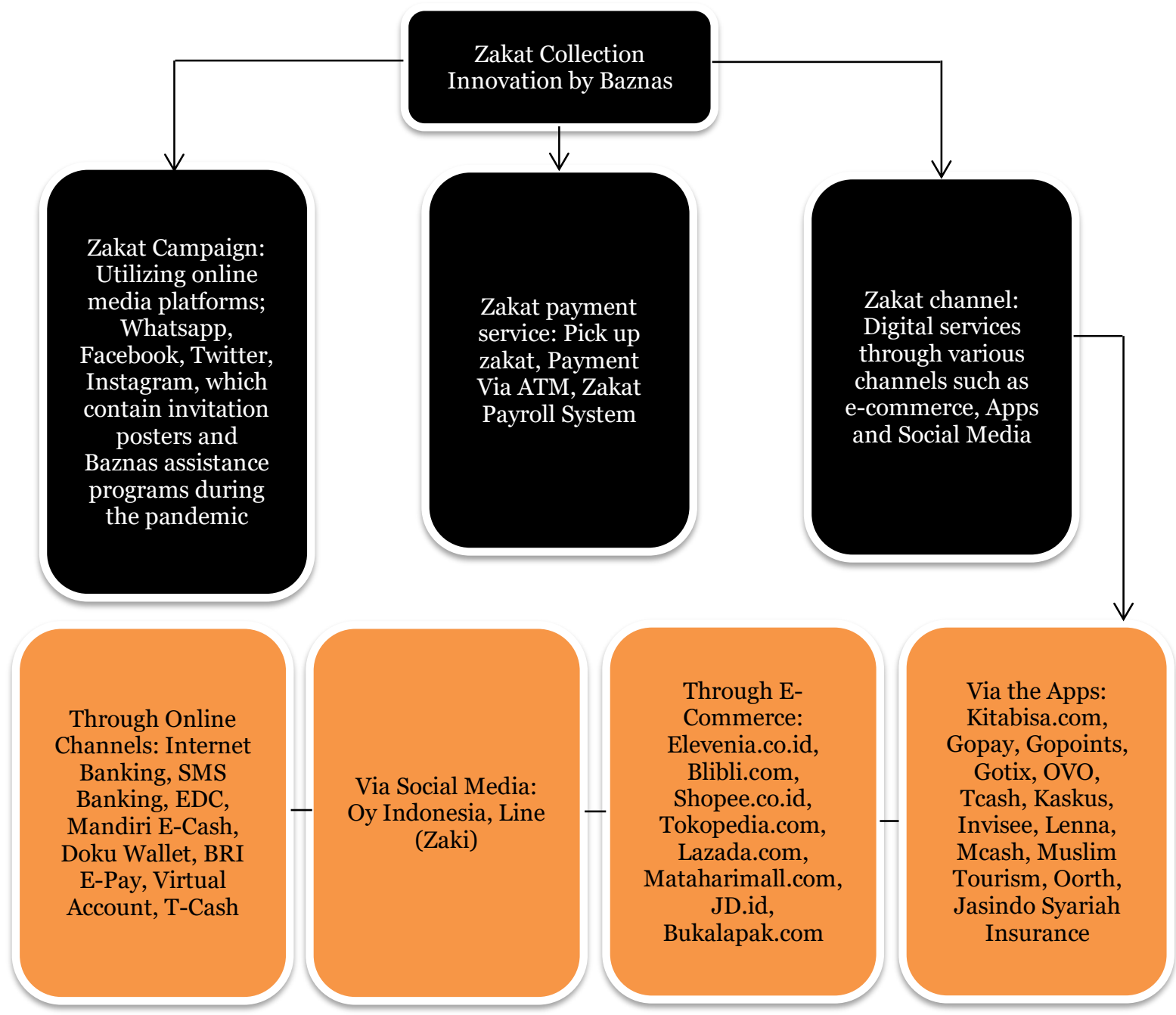

From the data found during January-May 2020, the collection of zakat funds has increased> IDR 211 billion with an increase of 70\% compared to the 2019 period. This indicates an increase in public awareness and confidence to pay their zakat, even though in theory the number of muzakki is affected by the economic crisis. due to the increase in COVID-19, so that people who reach the nishab of zakat are reduced, both employers and employees, it is estimated that zakat earnings will decrease. However, in this condition, many new muzakki emerged who were moved to help in handling 
COVID-19. At Baznas Sidrap the collection of zakat is carried out through a zakat collection service by contacting the Baznas Sidrap contact center and is carried out using a digital system through payment to the Baznas Sidrap account.

Zakat distribution and empowerment programs continue to grow and vary in meeting the needs of mustahik, there are five main programs implemented by Baznas, namely: social and da'wah programs, education programs, health programs, economic empowerment programs, humanitarian and disaster programs.

There are 6 important aspects used by Baznas as a guide in distributing Zakat during the COVID-19 pandemic, namely:

1. Ensure the distribution of zakat for handling COVID-19 by sharia law and the provisions in force in Indonesia.

2. Ensure that zakat distribution for handling COVID-19 does not violate the COVID-19 handling protocol.

3. Ensure that the ZIS distribution mechanism for handling COVID-19 uses a push approach (coming to those who need it) and not a pull approach (gathering people in need).

4. Strengthen coordination with the government / COVID-19 task force in distributing aid.

5. Determine 6 clusters or groups of Mustahik that are the targets of Baznas in distributing assistance, namely: teaching staff clusters, micro and small enterprises (UMK), formal labor clusters, clusters of layoffs, and unemployed victims.

6. Establish 2 Program Groups as vehicles for Baznas in channeling aid to deal with the economic and social crisis caused by the COVID-19 pandemic.

Mustahik Zakat in the

Alquran Surah At-Taubah verse 60

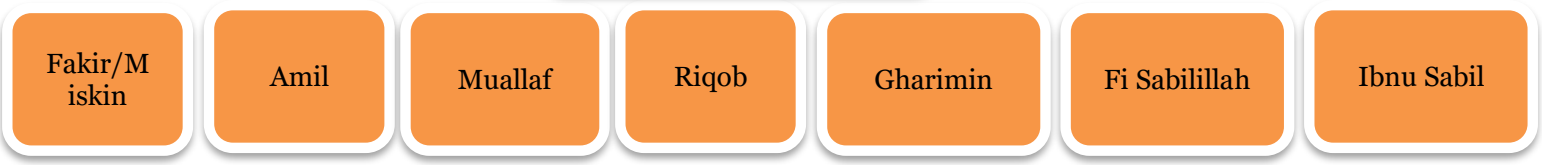

There are 8 categories of zakat / mustahik recipients as contained in the $\mathrm{Al}$ Qur'an Surah At-Taubah verse 60, namely:

1. Poor: A person who does not have a property and income or a job, at least 3 of the minimum basic needs are not met.

2. Poor: People whose wealth and income are not sufficient to fulfill / basic needs, or less than the nishab. Nishab can be measured as equivalent to calculating the nishab of gold or agriculture.

3. Amil: They are those whose job is to manage zakat and are paid from zakat which is equivalent to the market value of their work.

4. Muallaf: Those who have just converted to Islam. Assistance for temporary shelter or assistance for organizations conducting da'wah.

5. Riqob: Liberating people from slaves, prostitution, and oppressive power from other parties such as buying and selling of people. 
6. Gharimin: Debt to meet basic needs (needy, poor, and converts). Those who have loans, credit cards, education loans, or business loans.

7. Fi Sabilillah: Da'wah activities (individuals or organizations), seminars, workshops, and activities carried out by universities, schools, and associations that help develop Muslims, especially students and youth. Publications from da'wah.

8. Ibn Sabil: People who are on a trip and do not have enough money to pay for necessities during the trip, there are no relatives or guardians who are willing and responsible to help.

The Mustahik Zakat

Cluster during the

Pandemic COVID-19
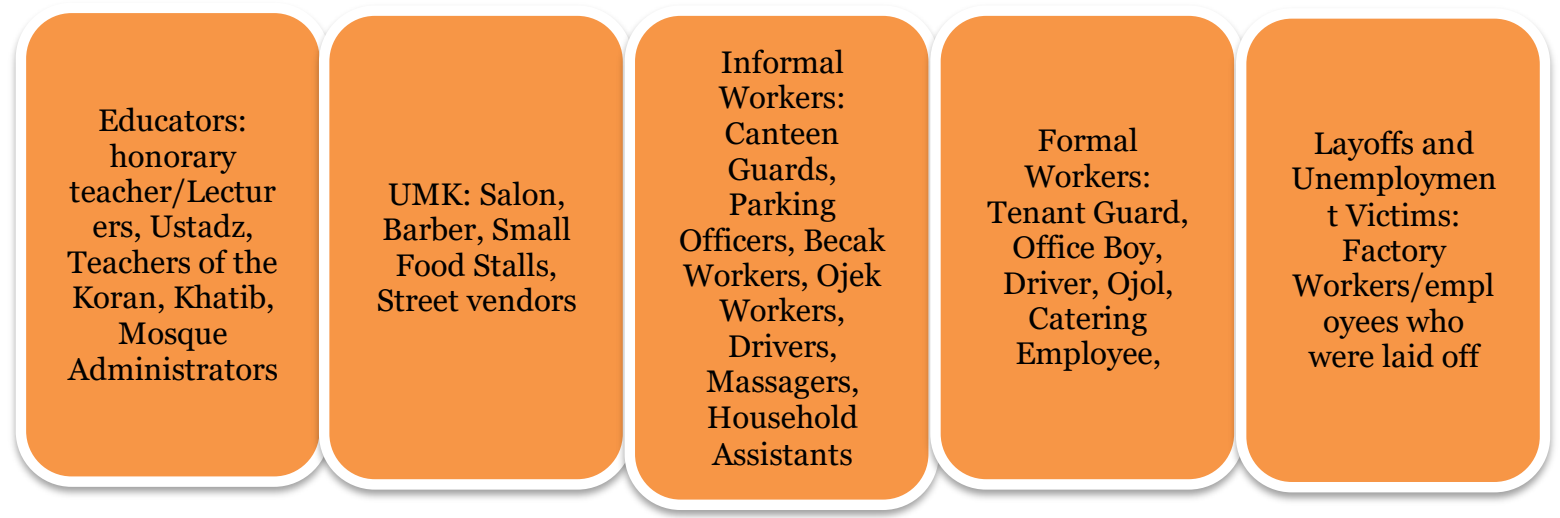

The COVID-19 pandemic emergency program carried out by Baznas in the distribution and utilization of zakat namely: health emergency programs and socioeconomic emergency programs.

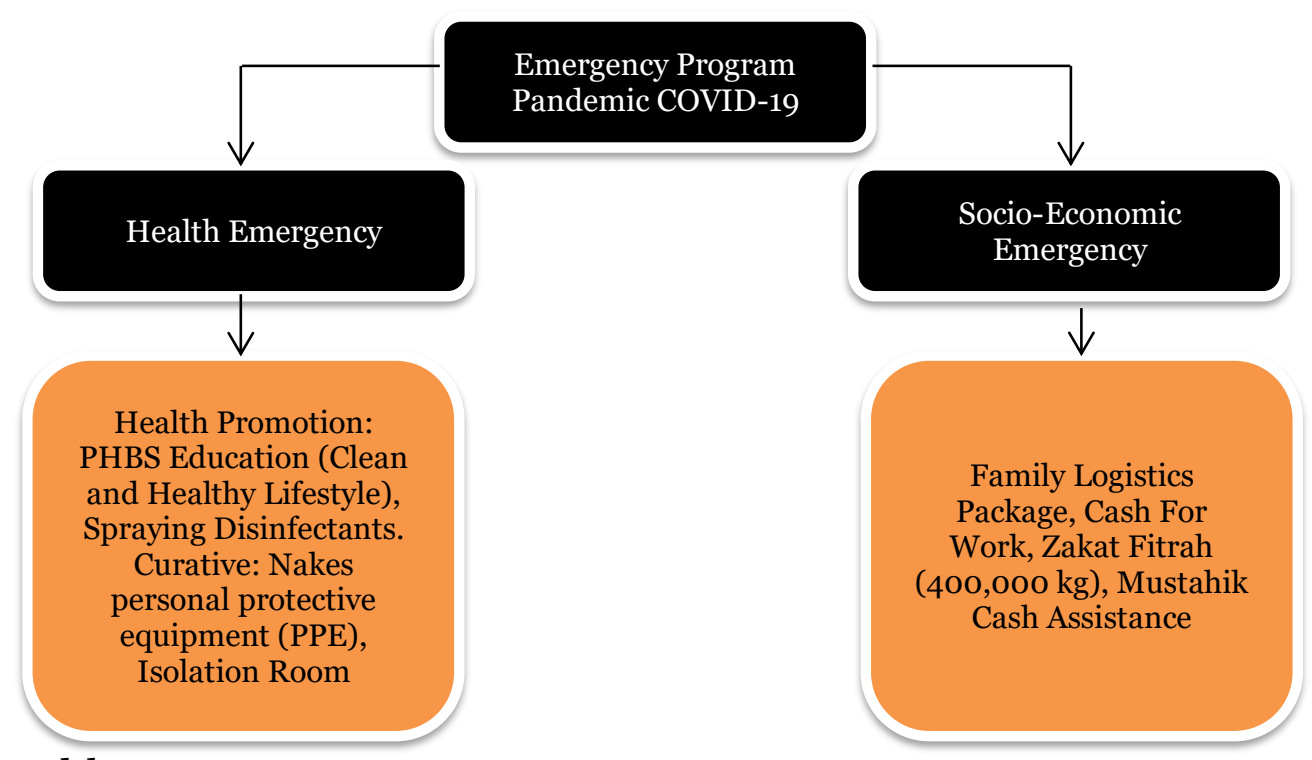

1. Health Emergency Program

In the health emergency program, Baznas has taken strategic steps including educating the public to maintain a Clean and Healthy Lifestyle (PHBS), spraying disinfectants in public places such as schools, offices, train stations, and terminals. 
Then, Baznas has also installed healthy sinks in several crowded centers to make it easier for people to practice washing their hands regularly. Baznas has also carried out curative activities including the provision of Personal Protective Equipment (PPE) for health workers who are distributed in COVID-19 referral hospitals and also providing isolation rooms for patients who have symptoms of being infected with COVID-19 in Baznas Healthy Home (RSB).

2. Social Economy Emergency Program

Baznas focuses the program on fulfilling the family logistics package which aims to maintain family food security amid the implementation of Large-Scale Social Restrictions (PSBB). Then, Baznas has also made an important innovation, namely the Cash For Work (CFW) program in which Baznas involves many informal workers affected by COVID-19 such as online motorcycle taxi drivers, public transportation drivers, manual laborers, buskers, and so on to work with Basnaz in spraying disinfectant in public places and they are rewarded for the work they have done.

Mustahik are also trained and trained to sew cloth masks, and honey producer mustahik have increased the volume of honey production for handling COVID-19. Then, the Social and Economic Emergency Program also prioritizes zakat fitrah to be distributed to families affected by COVID-19. Baznas also provides direct cash assistance to those in need in an effort to maintain their purchasing power amid the pandemic. The realization of zakat funds for the distribution of the Baznas program in dealing with COVID-19 is >IDR 7 billion.

Meanwhile, the distribution and utilization of zakat from Baznas Sidrap have channeled funds amounting to >IDR 600 million since the time of the COVID-19 pandemic with the main distribution of zakat funds to remote areas that have been affected by the COVID-19 pandemic, in the form of basic food assistance for the consumptive sector, and distribution of assistance to small entrepreneurs who are affected by COVID-19 for the productive sector.

\section{Realization of Zakat Distribution Funds}

\begin{tabular}{|l|l|}
\hline \multicolumn{1}{|c|}{ Baznas } \\
$\begin{array}{l}\text { Health Emergencies and } \\
\text { Socio-Economic } \\
\text { Emergencies }\end{array}$ & $\begin{array}{l}\text { Baznas Sidrap } \\
\text { Productive }\end{array}$ \\
\hline Rp. 7.578 .461 .063 & \multicolumn{1}{|c|}{ Rp.614.889.500 } \\
\hline
\end{tabular}

The COVID-19 outbreak is a test as well as a momentum for Muslims to actualize authentic religious values and messages by optimizing the role of zakat in helping our brothers and sisters in need. With zakat as a strong instrument and playing an important role in overcoming COVID-19 with real programs that help and empower mustahik.

\section{CONCLUSION}

Zakat for muzakki is worship to purify life and property. The collected zakat funds must be managed properly so that the distribution of zakat assets can be effective and on target to the mustahik. Baznas Sidrap has renewed zakat management 
both in terms of collection, distribution, and utilization of zakat funds. Where the maximum possible use of zakat funds for the welfare of the mustahik both consumptive and productive. In distributing zakat funds, Baznas Sidrap prioritizes the distribution of zakat funds to remote areas that have experienced the impact of the COVID-19 pandemic, in the form of food assistance for the consumptive sector, and distribution of business assistance to small entrepreneurs affected by COVID-19 for the productive sector.

\section{REFERENCES}

Didin Hafidhuddin. (2008). The Power of Zakat in a Comparative Study of Zakat Management in Southeast Asia. UIN Malang Press.

Didin Hafidhuddin. (2020). Contributions and Solutions of Zakat and Wakaf during Pandemic. https://bimasislam.kemenag.go.id/materiliterasi/materi1.html

Fakhruddin. (2008). Fiqh and Zakat Management in Indonesia. UIN Malang Press.

Kamaruddin, P. P. H., \& Amil, L. (n.d.). Potential of Zakat and Wakaf Indonesia.

M. Quraish Shihab. (1999). Alqur'an. Mizan.

Muin, R. (2011). Zakat Management. Alauddin Press.

Nurhayati, T., \& Halal, R, S. A. (2020). Emancipation Against a Global Pandemic; Evidence From Indonesia. Jurnal Adalah: Buletin Hukum Dan Keadilan, 4(1), 81-92.

Nuruddin, A. (2006). Zakat as an Instrument in Fiscal Policy. Rajawali Press.

P, A. B., N, A., Fathin, A., Ranggajati, A., W, A. D., S, D. R., Wijayanti, R., \& W., dan Y. M. (2020). Protecting vulnerable workers during and after a pandemic. Journal of Chemical Information and Modeling, 53(9), 1689-1699. https://doi.org/10.1017/CBO9781107415324.004

Putra, I., \& Dana, I. (2016). Effect of Profitability, Leverage, Liquidity and Company Size on Stock Returns of Pharmaceutical Companies in BEI. E-Jurnal Manajemen Universitas Udayana, 5(11), 249101.

Sahal Mahfudh. (2007). The professionalism of Zakat Management in the Nuances of Social Fiqh. LKIS Pelangi Aksara.

Susilawati, S., Falefi, R., \& Purwoko, A. (2020). Impact of COVID-19's Pandemic on the Economy of Indonesia. Budapest International Research and Critics Institute (BIRCI-Journal): Humanities and Social Sciences, 3(2), 1147-1156. https://doi.org/10.33258/birci.v3i2.954

Susilo, A., Rumende, C. M., Pitoyo, C. W., Santoso, W. D., Yulianti, M., Herikurniawan, H., Sinto, R., Singh, G., Nainggolan, L., Nelwan, E. J., Chen, L. K., Widhani, A., Wijaya, E., Wicaksana, B., Maksum, M., Annisa, F., Jasirwan, C. O. M., \& Yunihastuti, E. (2020). Coronavirus Disease 2019: A Review of Recent Literature. Jurnal Penyakit Dalam Indonesia, $7(1), \quad 45$. https://doi.org/10.7454/jpdi.v7i1.415

Valerisha, A., \& Putra, M. A. (2020). The Global COVID-19 Pandemic and Nation-State Problems: Data Transparency as a Socio-digital Vaccine? Jurnal Ilmiah Hubungan Internasional, 131-137. https://doi.org/10.26593/jihi.voio.3871.131-137 
WHO. (2020). Covid-19. https://www.who.int/indonesia/news/novel-coronavirus Zainuddin. (2013). Zakat Law. Alauddin Press. 